Thieme, T.A. (2016)" "This upgraded place is my bedroom, but the ghetto is my living room': Negotiating doing (too) well and belonging in the 'hood' of Nairobi slums," book chapter in Assembling Life at the Margins, edited by Michele Lancione, publisher: Ashgate.

'The Ghetto Will Always Be My Living Room': Hustling and Belonging in the Hood of Nairobi Slums.

\title{
Hustling on the Margins
}

This is the story about the journey of a young woman who grew up in one of the oldest and largest informal settlements of Nairobi. Eliza's story is inextricably tied to the broader narratives of hustling that feature centrally in everyday 'creolised argot' (Comaroff and Comaroff, 2005, pp. 28) amongst Nairobi youth making a living outside the formal economy. 'Hustling' in the Kenyan context has shaped youth identities and their norms of adaptation to everyday adversity and uncertain futures. Eliza was one of the key protagonists of my $\mathrm{PhD}$ research, in many ways epitomising and defying the logics of the 'hustle economy' (Thieme, 2013). Her journey included the impasses she faced as she aspired to do well - to get out just enough to be better off - but to stay anchored within the collective sub-culture of urban youth living in informal settlements or 'slums'.

This chapter is situated within efforts to theorise youth agency and struggle 'in the hood' by drawing attention to the economic, cultural, material, and political repertoires of largely unheard voices on the urban margins (Richardson and SkottMyhre, 2012; Jeffrey and Dyson, 2008; Honwana and De Boeck 2005). Increasingly, youth contest social and environmental injustices by connecting their marginalized status as formally jobless youth to unoccupied terrains of potential income generation to assert their place within their neighbourhoods and within Nairobi more broadly. Take the small scale but wide spread youth-led operations of waste work that have been taking place across slums of the city, born out of the city's gradual physical infrastructural decay since the 1980's combined with a widespread accepted informality in nearly all spheres of urban service provision (Huchzermeyer, 2010; Myers, 2005). [Insert Figure 7.1 here. Landscape] Figure 7.1: Mathare Valley rooftops. Photo taken by Tatiana Thieme, November 2009. 
Eliza grew up in one of the most congested low-income estates of Nairobi known as Huruma near one of the largest and oldest informal settlements (see Figure 7.1), Mathare Valley (Chiuri, 1978; Etherton, 1976). She was amongst the first generation of young Kenyans in the post-colonial capital who were born and raised in what most young people call the 'ghetto', and left to their own devices to make a living. The challenges and everyday struggle in the slums should by no means be romanticised, but it is worth emphasising that the hood has become generative in its own right, a context where traditional cultural norms and roles can be challenged, and where the regulatory and legalistic parameters of urban provisioning could be pirated and creatively circumvented (Sundaram, 2010; Mabala, 2011). The informal waste economy has placed formally invisible and ill-served pockets of Nairobi on the radars of multiple actors across government, business and NGO sectors (Thieme, 2010). The celebration of the informal sector in Kenya has raised polarised debates concerning the justification of state support retrenchment versus the normalisation and expectation that all the poor must be entrepreneurial subjects in order to survive, let alone thrive, in the harsh urban environment (Hart, 1973; King, 1996; Potts, 2007). But beyond the debate on state versus market mechanisms lies the subjectivities of these 'entrepreneurs' themselves that has been, to date, rather under-documented, particularly in the case of youth, and especially female youth.

Numerous urban sociologists have theorised urban marginality by focusing on the 'ghettos' of the US and Europe, highlighting the post-industrial economics, racial demographic segregation, and politics of welfare state retrenchment that have continued to further exclude urban 'outcasts' from mainstream urban society (Wacquant, 2008; Wilson, 1987; Comaroff and Comaroff, 2005). Similarly, youth studies have become a growing area of academic and policy interest, especially on issues of unemployment and the dangers of mass youth disaffection, portrayed either as the 'ticking time bomb' or the source of hope and innovation (Diouf, 2003; De Boeck and Honwana 2005; Jeffrey, 2012). While these are crucial contributions to the study of urban marginality, less attention has been paid to the internal cultural and material logics that inform everyday rationalities and experiments in precarious urban life (Gidwani, 2001; Simone, 2010). These include existing coping strategies of youth whose life, work, identities and place within cities is often stigmatised and defined by negation, categorised as unemployed, idle, or a perceived nuisance for 'hanging about', loitering or making trouble (Jones, 2012; Borden, 2001; Weiss, 2009; Thieme, 
2013). Young women's stories and their own paradoxical subjectivities merit particular attention (Dyson, 2009). They occupy the liminal and politicised status of 'youth,' whilst also epitomising the everyday negotiations with gendered expectations associated with domestic responsibilities, traditional land inheritance norms, and stigma associated with teenage pregnancy and single motherhood.

The study of hustling builds on conceptualisations of the nexus between urban poverty and youth, reflecting everyday struggle in the face of extreme urban social environments and prolonged precarious conditions. Ethnographic accounts depict youth in various geographies navigating uncertain futures by engaging in 'modernity bluffs', finding creative channels to express disaffection, and shaping a kind of 'zig zag capitalism' based on the ingenuity of forced adaptation to rapidly changing cityscapes (Vigh, 2006; Jauregui, 2014; Fredericks, 2014; Waage, 2006; Jeffrey and Dyson, 2013; Newell, 2012). What has not been explored in depth are the internal frictions between those who stay 'stuck' in the poverty trap and those who manage, albeit in incremental ways, to do well, but whose subjectivity and sense of place is anchored in the hood, to the extent that negotiating everyday social life, work, and place renders hustling a performative practice. Hustling, for Eliza, involved moving in and out of the hood at various stages of her formative years, and managing the social ties that made these streets her base but also at times a potential trap. Eliza's story sits within broader post-colonial critiques of urban studies, by re-thinking and theorising subjectivities of marginality from the South (Comaroff and Comaroff, 2012; Robinson and Parnell, 2012; Myers, 2011), and more specifically from the hood where adversity and frustration are co-constitutive with alternative coping strategies and learning that shape particular experiences and attitudes (Richardon and Skott-Myhre, 2012; McFarlane, 2011). Understanding how slum dwellers navigate uncertain futures requires a critical engagement with the very expressive articulations our interlocutors deploy in everyday parlance, harnessing the everyday argot as potential analytical repertoires of critical urban studies. It is in this spirit that this chapter tells a story of hustling on the margins, seeking to emphasize the point of view of someone on the inner edge of the margins.

\section{Ethnographic Encounters}


This chapter is an exercise in ethnographic portraiture (Jeffrey and Dyson, 2008), seeking to privilege the multitude of insights, the simultaneous impasses and possibilities and paradoxical subjectivities of a singular informant. Eliza's story is set within the broader context of an ethnographic study on Kenyan youth's diverse everyday strategies and experiences in navigating uncertain urban terrains, and how some youth have managed to appropriate their marginalised and liminal status to render 'the ghetto' a place of possibility. Elsewhere I have located the epistemologies of 'hustling' within everyday banter, accounts of life on the streets, articulations of struggle, work, and aspirations. These accounts emphasize the interpersonal dynamics and social ties that are integral to the hustle in the hood, which paradoxically are consistently anchored in the collective unit of the 'group', but sometimes erode solidarity and possibilities to do well (Thieme, 2013). While the hustle economy displays modes of improvisation and adaptation that engage with capitalist relations and entrepreneurial urbanism, it does not necessarily equate individualistic, selfinterested pursuits of continuous and limitless economic gain, or desires for differentiation (Thieme, 2015). The hustlers' skill is instead to strategically modulate between survivalism, livelihood strategy through diversifying sources of opportunity to mitigate risk, and contestations of authority. The tenuous balance between feeding themselves and renegotiating their place within the city is at the core of urban hustlers' subjectivity.

Eliza's story told below is based on our countless private conversations recorded during my homestays with her and our numerous walk-abouts in her neighbourhood between 2009 and 2012, a series of detailed life history interviews conducted in 2010, and the informal group bantering between Eliza and her male friends with whom she had grown up, played football, worked as a garbage collector, mentored, and eventually bossed around as a sanitation entrepreneur and team leader. The story is largely told through my narrative voice, but seeks as much as possible to have the palimpsest of her words, expressions and experiences come in the foreground, as quotes from various recorded conservations are interwoven into the text. This chapter seeks to reflect the meaningful though inevitably partial encounter of ethnographer and interlocutor. It offers an assemblage of academic reflections concerned with the core theme of this book on urban marginality, by emphasizing the interpersonal palpability of the field in all its fragility and serendipitous experimentation through a mosaic of exchanges, where Eliza let me into her life 
world, and allowed me to ask her to articulate things that she had never been asked to reflect on before.

Eliza was in her early twenties when we met, and she embodied the paradox of youth growing up in Nairobi's urban slums. Her story as a single mother who got pregnant before finishing secondary school was typical in these low-income neighbourhoods, where countless teenage girls ended up having their youth prematurely truncated by unintended pregnancy, and the social stigma that followed the experience of being a young single mother. These two factors, single motherhood and the inability to afford living on her own, exemplified the protracted liminality of youth living in urban poverty in Nairobi (Thieme, 2013). On the one hand youth were forced to 'grow up' quickly and assume adult responsibilities, on the other hand the lack of job opportunities and ability to afford housing typified youth's inability to attain certain key markers of adulthood such as a secure source of income and being able to afford 'your own place'. This was all the more significant for young women who were the de-facto primary carers of their children, as well as often dutifully tending to their elders.

At the same time, Eliza had defied the stereotypical ripple effects of single motherhood and youth unemployment. She had not dropped out of school when she got pregnant, instead finishing her secondary school against the odds. And she challenged gendered norms of her local entourage by inserting herself in the maledominated informal economy of garbage collection that had become one of the main sources of income generation for young men 'in the hood'. Eliza always felt more comfortable hanging out with the guys. She boxed, she played football, she was garbage collector, and was able to partake in the macho banter with her male peers but in a way that playfully ridiculed their ways whilst appreciating their highly sexist humour. For at the end of the day, Eliza would never be one of those women that her friends referred to, the mistress or 'girl on the side,' or 'Mpango wa kando' (spare part) as the expression goes, but nor was she the girl that the guys courted either. She was their friend, their sister, in some instances their boss.

But as a young single mother, she also embodied the plight of young women living in the slums, knowing what it was like to navigate uncertainty and adversity in a neighbourhood where basic necessities like finding a clean safe toilet were a security concern, and where countless teen-age girls who fell pregnant had slept with men in order to get some money for food, phone credit, or even sanitary pads. Eliza 
related to her female counterparts especially when she spent hours at the hair salon getting her braids done every few weeks, and retained within her garcon manqué ways a modicum of coquetries and female complicity that gave her a foothold amongst the women in her neighbourhood. It was this dual position as a single mother who understood what it was like to grow up and raise a child in the ghetto, and her role as a youth female activist and waste worker hustling on the margins of the informal economy that accorded her a unique street credibility amongst both her female peers and her male peers.

\section{Life in Huruma's Hood}

Eliza was born in Huruma in 1987, where she spent her childhood and early adult years. She had four brothers and one sister, all born in Nairobi. When I met Eliza in 2009, she lived with her parents, two brothers, and her son in a two room flat on the bottom floor of a four-story tenement walk-up in the middle of Huruma, one of the most densely populated low-income 'estates' in the world, adjacent to Mathare Valley. One room consisted of a double bed for her parents, a small coffee table sandwiched between the bed and a two-seater sofa, which turned into a makeshift bed for Eliza's seven-year old son, and where most of the family assembled to watch television on a twelve-inch screen perched on a tired-looking wall unit that marked the spatial separation between the 'bedroom' space and the 'living room' space. The second bedroom had one single bed for Eliza's older brother, and a mattress on the floor against the iron sheet wall for Eliza. Between these two rooms, a small separate utility space was used for cooking and storage. The toilet, bathing stall, and water tap were down the hall and shared across all the families living on that floor. Although this part of Huruma was electrified, blackouts were a daily occurrence, and little pieces of waxed candlesticks were seen in most corners of homes and the common washing area, serving as makeshift lights after sundown. [Insert Figure 7.2. Landscape] Figure 7.2: Room with a view. Photo taken by Sasha Turrentine, May 2010.

As was typical for most children born in Nairobi's low-income settlements in the 1980's, her parents were from one of the rural provinces in Kenya, and had migrated to the city for the father's work. As Eliza explained during one of many recorded life history interviews, 
'He was employed by the government. I think he was an accountant for the NSSF (National Security Social Fund). Mom was a businesswoman. She was selling second hand clothes. Eventually the business collapsed. My childhood was not bad because at the time I was being brought up, my dad was still working. But by the time I was thirteen, my dad stopped working. I don't know what happened to the job. That is where life became difficult.'

Although Eliza's father had been out of work for years, her father's former status as a government employee was an important part of the family folklore and pride. The second hand clothing market, in which Eliza's mother was a 'business-woman', was a large but saturated share of the informal street vending economy in Nairobi, and it was common for individual entrepreneurs in the second hand market to give up their business at one stage or another, due to the significant logistical and economic challenges associated with inventory space, vending stall rental cost, and keeping up with local competition. When both her parents were out of work, Eliza's oldest brother, who had just finished secondary school, 'took care of the family. When she spoke about this period in her childhood, she evoked a sense of gratitude towards both her brother and the benevolence of her primary school, as though inferring that this was unusual fortune within the slums. Referring to her brother, she explained,

'He was just doing some casual jobs. He was able to take care of the whole family, because the little he could get he could pay for food. I went to St. Benedict's school, and it was a church school so they were understanding if you couldn't pay for school fees. You would still have to pay, but you could pay in instalments. My favourite subjects in school were English, maths and science. In 2002, I took my KCP exams, the first national examination at the primary level. At that time my brother was still taking care of us, because my dad still wasn't working. I did the exam without paying because they understood my situation. I did my class eight for free, I never paid. They were understanding. I liked school.' 
Eliza's brother had become the sole bread-winner of the family by the time he completed school. It was not uncommon for a young member of the household to take care of the whole family in these neighbourhoods. What was less common was young people finishing secondary school, partly because this part of Nairobi had very few secondary school options and unlike certain benevolent primary schools, most secondary schools were fee paying and did not accommodate for financial aid. Eliza had spent her early teenage years with her brother's example, hustling in the informal economy, generating income wherever an opportunity arose, and as long as his parents were out of work and younger siblings were in school, it was a given that the eldest child's obligation was to provide for the rest of the family. Eliza was influenced by her brothers and older boys around her neighbourhood in other ways as well. By the age of 15, Eliza's social and recreational activities were often spent hanging about with an array of 'big brother' figures who taught her how to train, how to be tough, how to defend herself. As she put it,

'My best childhood memories were playing football and boxing. I was usually training mostly with boys. My brothers were all boxers. So I was just going with them to see them train, and then I started training with them too. The women didn't think it was strange, because they knew I grew up with only brothers, so they thought I was just more comfortable with the boys. But the boys they were cool with me because they saw that I was not like the other girls.'

In 2003, Eliza joined a nearby secondary school. But within a few months, Eliza realised she was pregnant and dropped out of school. The tone of her voice and facial expression changes suddenly here. She recalled,

'After that life became difficult. My parents weren't very happy with me. My older sister was not really around because she is married. You know, the situation was such that I was the last born, and now pregnant, so it was a situation whereby everyone is against you. At that point, I was really scared. So I went to stay with my friend for some months. Then I met with my brother who told me to come back home. When my family finally accepted the situation, they said, "The fact remains that 
you are our daughter and our sister." On November $13^{\text {th }}$, I gave birth to Kevo. I was seventeen.'

Despite the commonness of teenage pregnancies in urban low-income neighbourhoods, the social stigma associated with teenage pregnancy was, as Eliza described, a kind of 'curse'. Her father and brothers had stopped speaking to her for a time, and the mothers of her friends forbade them to socialise with Eliza for fear that she was a bad influence. But Eliza reflected on this period as both a time of social exclusion but also an affirmation of her independence. With modest pride and a slight smirk, she recounted how,

'Even those same girls whose mothers were saying, "don't play with her," many of them fell in the same trap. They got pregnant and they are worse off than I am because they went for early marriage, which they could not cope with. At least me, I'm just there.'

What Eliza meant by 'I'm just there' was that she was not forced to go into early marriage. She recollects her eldest brother being the central source of encouragement in this regard, insisting that,

'We'll support you, just give birth and have the baby, we'll help you take care of the baby. Then you'll go back to school.'

After Kevo was born, Eliza took a hairdressing course. Hair salons were one of the most common local businesses in the slums and most women paid up to $1000 \mathrm{KES}$ (approximately 10 USD) to get their hair braided, equivalent to nearly a third of one month's rent in Huruma. Eliza spoke about the course as a transient phase.

'The training took nine months. I would go with Kevo to the daycare, and then to the college for my course. After that I did salon work for two to three months but it wasn't good because my boss saw me as someone who just got out of school without much experience, so he would give the other ladies the work since they were more expert. Since it was a commission-based job, I wasn't earning much so I decided to 
leave. My brother was not very happy because he had paid for the course. I told him I would try my best, and look for another place.'

Eliza admitted that she did not like hairdressing, and even less being bossed around with little prospect for advancement. She also intimated that she preferred to work independently, and following her hairdressing course started experimenting with various modes of self-employment. Working in one place for two-three months, she would use her saved earnings as seed capital for a small business idea, such as selling rice in her neighbourhood. Eliza travelled long distances once every two weeks to purchase rice at wholesale prices, and then sell a kilogram of rice through door-todoor sales to people she knew. She made a small profit on sales and saved on overhead costs, and her customers saved money by paying less than the local retail price. But as with any business in the hustle economy, there were inevitable blockades even in seemingly lucrative and well-oiled business models, which required quick adaptation and improvisation. When the price of rice went up, Eliza gave up the rice distribution business, and turned to her male peers and child-hood friends, who by then had all finished or dropped out of secondary school. Most of them were engaged in waste work, which had become a common entry point into the informal economy in slums all over the city, as a result of ever-growing demographic growth with an ill equipped municipality to service low-income areas. As the local refrain put it, 'trash became cash'. Eliza's eyes lit up when she started to explain the early days of her work with tako (garbage), acknowledging that what seemed at first like dirty work had in fact permitted her to adapt her skills. She explained,

'I started garbage collection. I just approached some of the boys and asked them, "Please can you call me even if it's commission I'll take the job." No matter what the job, I'll do it so that my child can eat and be dressed. I didn't mind what the job was. I had gone to these workshops and I was well informed and was determined to earn a living for my son.'

This was in 2005, and no other women were doing garbage collection at the time. Eliza spoke about being the only woman 'doing this kind of job' in a way that highlighted the physical demands of the work and the pejorative associations with 
handling garbage. But her recollection of this work also emphasized the pride of being part of a largely youth-based entrepreneurial economy, and doing something that the local government had failed to provide: deliver basic waste management to a residential community.

On the one hand Eliza admitted to being desperate enough to do almost any kind of work if it would support her son and the rest of her family, on the other hand like many other youth who had grown up in the 'ghetto', there was a deliberate choice in doing 'dirty work' on their own terms over 'donkey's work' for an exploitative or abusive boss in the industrial area of the city. Indeed working for someone else, for this generation of Kenyan youth, recalled highly uneven power relations and exploitative practices between employer and employee. Working for yourself, and amongst fellow peers, anchored in friendship based youth groups, was integral to the collective identity of many young people living in the slums who claimed to enjoy the relative freedom of circumventing both formal state and formal market channels of service provision, employment, and control.

In addition to her income generating work, Eliza was also a peer educator for young girls in her neighbourhood, something she had become involved with following Kevo's birth in pursuit of a support network for young mothers in the slums. It was this network, she claimed, that helped her finish her KCSC exams in 2006, finally completing secondary school.

'When I got that training, I learned that even if you are pregnant, even if you have given birth (as a young girl) that does not mean that it is the end of everything. When I finished my Form Four exams, after that, people were proud of me. I started seeing some of the girls who were stressed with life saying, "after all, I've become pregnant. I have a child. Look at my family situation, what will I do? My only option is to go for early marriage." That's where I would chip in and say, "No, you have other options. You are now eighteen years old. If you get married now, where do you think you will be in five years? Why can't you change your life and change your community?"”

Eliza informally mentored other young women who experienced teenage pregnancy to think about their options beyond early marriage. As she put it, 'for young women in 
the ghetto marriage is often an issue of peer pressure. You feel as if you are pushed against the wall.' Eliza's motto was that being single enabled a woman in the ghetto to think about her future. For her, that meant thinking about what it would take for her son to realise his potential, and to eventually attain the status of manhood according to her cultural tradition.

'For me personally, getting married is not an issue but what's an issue is having my little boy ask me, "where is my father?" You see, the other thing is in the slums, if you get married and you already have a child, that family won't see your child as part of the family. If I got married my son wouldn't feel accepted into the family. And you know Kenyan men, even if you have a boyfriend, he'll not take care of your baby. So it's up to you as a mother to do it. First and foremost the single mothers will think about their child. The relationship with men comes second. But the bigger issue for me is one day having my son be able to say, 'there is my land'. Having some property for him. That is what I'm thinking of getting married. If I can provide him with a good situation, having some land where he can go, he will never ask you "where is my dad" or things like that, because I will have given him something of his own.'

Here is where Eliza's story underscored the dialectics of identity for female youth living in the city. For her it would be paramount for Kevo to one day have land of his own. In her tribe, this was only possible through patrilineal heritage, where land was traditionally passed on from father to son. But without a father, a 'bastard son' would never be given land by a father figure. Any new man Eliza would let into her life, she explained, would never accept, let alone adopt, Kevo as his own son. Eliza's goal, what drove her everyday ambitions, was the notion that she could one day afford to buy a plot of land for her son, preferably somewhere that fit the rural imaginary, away from the city (the country was colloquially referred to as 'shags'). To have a claim to some land in 'shags' was an important part of one's narrative, because even for youth who were born and raised in the city, they were (their kin, their tribe, their family farm) nevertheless from somewhere up-country. In this, she abided to traditions 
around gender and land inheritance. The means to this end would however be achieved by defying gendered norms of behaviour and practice.

In 2008, Eliza was one of the few dozen waste workers in Nairobi slums who became involved with a social enterprise called Community Cleaning Services (CCS). CCS was a Kenyan micro-franchise, sponsored by an American company committed to improving sanitation poverty through grassroots partnerships with low-income entrepreneurs who would offer cleaning services focused on shared public and community toilet facilities (Thieme, 2015). Eliza quickly went from being a team member of one of the CCS Mobile Cleaning Teams (MCTS), to a team lead and mentor, to a salaried CCS Professional responsible for training, and following up with different CCS teams across Nairobi and reporting back to the Central CCS Management team. By time I met Eliza in 2009, she had become the sole breadwinner for her family, with her parents and siblings each out of work, and her six-year-old son in primary school.

\section{'If They Know How Much You Make, Everyone Will Come Over For Lunch'}

In each neighbourhood within Nairobi slums, there were informally marked territories known to youth groups as 'the base', where domestic, social and business spaces often overlapped. The base of youth groups served an important geographical and social function. For instance, one of the youth groups Eliza frequently visited had a base situated at the bottom of the first hill hundred meters from the Matatu stage on the main road linking Mathare Valley to the Central Business District. It was next to a public toilet they built and managed since 2007. The guys could be found sat under a small wooden shed, where they had multiple angles of visibility. They could see who was coming from the stage, what the elders were doing on the other side of the footpath (often playing a local version of checkers and discussing local politics), they could collect payment for the toilet and water point both meters away from where they sat, they could see their urban farming corner to the left, their office to the right, and have a perfect view across the Mathare Valley. The base enabled peer groups to combine moments of loitering and killing time with a constant low-level flow of income generation that asserted their place and legitimacy in the public space of the neighbourhood. Eliza's street credibility involved having the license to kill time with these youth groups whose everyday practices blurred the lines between work, leisure, and idleness. 
Although the base comprised an informally marked territory in the neighbourhood for most groups, there was always a kind of headquarters or sitting corner where the group assembled, greeted, schemed, hung out, bantered, began or ended their working ventures. The base was a meeting point, where you could be found, where you belonged and where you were known. It informed street credibility and relationships to the base had everything to do with one's visibility. When it came to garbage collection and servicing the plots of other tenants, youth asserted, 'You do not go beyond your base.' This relationship between economic activity and territorial zoning related both conceptually and practically to codes of youth group culture, reflecting a key characteristic of the informal waste economy: the small and fragmented scale of these otherwise neighbouring enterprises.

Contrary to most conceptions of entrepreneurship informed by neo-classical economic theories, the aspirations of these youth hustlers did not include maximizing growth. Eliza frequently revealed to me the potential negative effects of doing 'too well', and explained why youth were deliberately elusive about how much they earned, and how. As Eliza explained,

\footnotetext{
'Most youth don't want to admit how much they earn-even to each other. When you seem like you make more than your neighbour, you can get into trouble. And if you do well and everyone knows it, then you'll find you have lots of friends coming over your place right before lunch time!'
}

Youth's individual strategic discretion regarding income was tied to the mtaa (hood) logic of solidarity inherent in everyday struggle. From the hustler's perspective, being part of a collective offered the benefit of risk reduction by diversifying ownership and reducing the traceability of any individual's gain from the entity. The difficulty of group membership, however, transpired for aspiring entrepreneurs setting themselves apart from group activities to pursue their individual ambitions while retaining a sense of belonging to the mtaa, their base, and their cohort.

In Huruma, Eliza was a self-proclaimed hustler, one of the guys, and part of the city's underworld. But part of maintaining her hustler persona vis à vis her peers within the mtaa required concealing to an extent that she was 'doing well'. Eliza had spent years struggling as a single mother pursuing various kinds of informal work 
while trying to finish school and manage her family obligations. When she started garbage collection work in 2005-2006, her entrepreneurial and resourceful capabilities coupled with ambitions to provide for her son as a single mother accelerated her productivity compared to her peers. It was this motivation that also fast-tracked her trajectory from member of a CCS team, to lead entrepreneur with multiple teams in Huruma, until she was finally hired by CCS as a full-time employee. [Insert Figure 7.3 here. Landscape] Figure 7.3: Eliza with the boys, outside a public toilet at the end of a cleaning job. Photo taken by Kennedy Kariuki, April 2010.

Her drive to prove herself within a male-dominated macho work culture defied commonplace outcomes of so many young single mothers in the hood, but her place within the traditional youth-elder hierarchies also meant that there would be no foreseeable end to the obligation to provide for the rest of her family with whom she still lived: her parents and two older unemployed brothers. Once the pride of being the main bread-winner subsided, she realized that her doing well gave her brothers little incentive to actually find work, and perpetuated a cycle of deference to her parents who expected her to share her earnings with the whole family as part of the reciprocal exchange involved following years of childcare support. As Collins et al $(2009,2)$ state in their reflection on the vicissitudes of the informal economy, 'you make more on some days, less on others, and often get no income at all. Moreover, the state offers limited help, and, when it does, the quality of assistance is apt to be low. Your greatest source of support is your family and community, though you'll most often have to rely on your own devices.'

By early 2010, Eliza had saved up enough money to move out of her childhood home in Huruma, encouraged by a family friend to move far from Mathare area to assert and protect her financial and personal space. Six months later, she sent her seven-year-old son to boarding school, which was revered in Kenya as a tremendous education opportunity for any child, especially for anyone living in the slums where the quality and resources for formal education were scant, and where most mothers complained that the temptations for young men in the slums to get involved in drugs, street crime and other kinds of trouble were constant. In theory, this twenty-three-year-old woman had 'made it.' But when she moved away to a lowmiddle income estate in the northeastern part of Nairobi, far away from everything and everyone she knew, Eliza admitted to feeling lonely and detached. During a 
follow-up visit in 2011, as we walked to her place one evening I asked her if this neighbourhood was starting to feel like home. She said no, and as she often did, put it metaphorically, 'This estate is my bedroom. But the mtaa in Huruma is still my sitting-room.' Her work and social ties remained in Huruma. It is where she spent her Sundays, where she went to get her hair braided, where she hung about with the guys at their respective bases in between jobs.

\section{Negotiating Worlds Within and Between Lives in the Hood}

The 'hustle' described in this chapter shows that the hood is not merely a temporary 'stop gap' for the emerging middle classes of $21^{\text {st }}$ post-colonial cities, but rather an urban form in its own right, where social and economic spaces are being shaped by a generation of youth caught between life worlds and contrasting imaginaries. It has produced a generation of youth whose entanglements with everyday struggle shape their perceptions of the future, but the small nodes of external support, encouragement, and nudges to keep aspiring are both critical and fragile.

Since 2011, many notable events have marked Eliza's circumstances. In 2012, her family's farm up-country tragically burned down one night. The following day, her entire savings (almost 2,000 USD) went towards emergency expenditures. She had been 200 USD away from buying Kevo a plot of land she had had her eye on since 2008. In 2013, CCS had to close down, and Eliza lost her job. She immediately started another business, selling non-perishables in the now growing neighbourhood where she lived, and she continues to work on sanitation related projects across Nairobi, trying to revive CCS in some form. In 2014 she gave birth to her second child, telling me with a mischievous giggle over the phone that, 'Kevo needed a baby sister'. She is still single, Kevo is still in boarding school, and is adamant that he wants to one day become a doctor.

Eliza's experience illustrates the relative social exclusion that resulted from 'doing too well', conflicting with the strong sense of belonging that resided in youth who hustled within their base for the majority of their formative years. As Eliza defiantly claimed during my last visit, 'It's important to leave the mtaa and your base at some point, because it's not everyone who will be happy with your progress.' Yet, despite residing elsewhere, affording higher rent and upgrading living standards, Eliza and others like her continued their ties to the hood and the hustle economy. Being from the mtaa equated a kind of badge, giving way to reverse prejudice towards 
young people in the city who romanticised and faked being from the hood. Where you eventually 'stayed' mattered less than where you had grown up, and where you went to socialize. Amongst those who had grown up in the hood, who worked where they lived and for whom, 'in the ghetto, business is social,' there was a perceived limits to growth and a cost to doing too well that was inextricably tied to one's street credibility as a hustler.

Eliza's life history shows how identity and sense of belonging were contingent on the protracted liminality of hustling, and how she negotiated the social implications of 'doing too well'. She chose to pursue her aspirations combining social work, activism, entrepreneurship, and further education, but has had to navigate the micro-politics of the hood amongst youth who know no other life world. Strategic discretion about income, returning each afternoon to loiter alongside the jobless corners of her peers, or combining formal education and 'advancement' with a loyalty for learning the streets; her story relays the complicated dynamic of a young single mother navigating a post-colonial city, where the contradictions of modernity, makeshift urbanism and alternative politics of struggle that evade traditional avenues of political resistance and mobilisation are redefining the terms of urban dwelling on the margins.

Eliza epitomises the paradox between youth disaffection with existing realities of urban injustice, and the commitment to stay fixed within the very neighbourhoods that exemplify the injustices associated with slum urbanism. Somehow, losing her savings and her stable CCS job never seemed to pose catastrophic results for Eliza. She managed, at every hurdle, to tap into 'zig zag' entrepreneurialism and hustle her way to the next opportunity. What seemed more difficult for Eliza was balancing her époques of sustained financial success and her place as a fellow hustler in the hood. Caring to maintain that balance kept Eliza and others like her in a kind of middle zone, where hustling was partly aspirational and filled with hopes to fight the traps of poverty, but where losing one's identity as a hustler came at a tremendous social cost. Her story depicts the paradoxical subjectivity of young people for whom growing up in challenging neighbourhoods can require negotiating the fine line between aspiring to get out of the quicksand of urban poverty, especially for young women, while choosing to remain rooted in the struggle of urban life in the hood. That struggle, embodied in everyday hustle, has become integral to the street credibility, belonging, and solidarity of young people growing up in this African city. 


\section{References:}

Anderson, E., 1999. Code of the Street: Decency, Violence, and the Moral Life of the Inner City. London: Norton.

Borden, I., 2001. Skateboarding, Space and the City: Architecture and the Body. London: Bloomsbury Publishing.

Collins, D. et al, 2009. Portfolios of the Poor: How the World's Poor Live on \$2 a Day. Princeton: Princeton University Press.

Comaroff, J., and J., Comaroff, 2005. Reflections on Youth: From the Past to the Postcolony. In Makers and Breakers: Children and Youth in Postcolonial Africa, eds., Honwana, A., and DeBoeck, F. Oxford: James Currey, pp.19-31.

Comaroff, J., and J., Comaroff, 2012. Theory From The South: Or, How EuroAmerica Is Evolving Toward Africa. Colorado: Paradigm Publishers.

Chiuri, W., 1978. Mathare Valley: A Squatter Settlement in Nairobi: A Case Study. Nairobi: UNICEF.

De Boeck, F., and Honwana, A., 2005. Introduction: Children and Youth in Africa. In Makers and Breakers: Children and Youth in Postcolonial Africa, eds., Honwana, A., and DeBoeck, F. Oxford: James Currey.

Diouf, M., 2003. Engaging Postcolonial Cultures: African Youth and Public Space. In African Studies Review 49(1), pp.1-12.

Dyson, J., 2008. Saka: Growing Up in the Indian Himalayas. In Telling Young Lives: Portraits of Global Youth, Jeffrey, C., and Dyson, J., eds. Philadelphia: Temple University Press.

Etherton, D., 1976. Mathare Valley: A Case of Uncontrolled Settlement in Nairobi. Nairobi: University of Nairobi, Housing Research and Development Unit.

Fredericks, R., 2014. 'The Old Man is Dead': Hip Hop and the Arts of Citizenship of Senegalese Youth. Antipode, 46(1), pp. 130-148.

Gidwani, V., 2001. The Cultural Logic of Work: Explaining Labour Deployment and Piece-Rate Contracts in Matar Taluka (Gujarat) India, Part I and Part II, Journal of Development Studies, 38(2), pp. 57-108.

Hart, K., 1973. Informal Income Opportunities and Urban Employment in Ghana. Journal of Modern African Studies, 11(1), pp. 61-89.

Huchzermeyer, M., 2011. Tenement Cities: From 19th Century Berlin to 21st Century Nairobi. London: Africa World Press.

Jeffrey, C., 2010. Timepass: Youth, Class, and the Politics of Waiting in India. 
Stanford: Stanford University Press.

Jeffrey, C. 2012. Geographies of Children and Youth II: Global Youth Agency. Progress in Human Geography. 36(2), pp. 245-253.

Jeffrey, C., and Dyson, J., 2013. Zig Zag Capitalism: Youth Entrepreneurship in the Contemporary Global South. Geoforum. 49, pp. R1-R3.

Jeffrey, C., and Dyson, J., eds., 2008. Telling Young Lives: Portraits of Global Youth. Philadelphia: Temple University Press.

Jones, G.A., 2012. Book review: Hang about: Young People's Frustrations at the State of Progress. Dialogues in Human Geography, 2(1), pp. 101-104.

Jauregui, B., 2014. Provisional Agency In India: Jugaad and Legitimation of Corruption. American Ethnologist, 41(1), pp.76-91.

King, K. 1996. Jua Kali Kenya: Change and Development in an Informal Economy 1970-1995. London: James Currey Ltd.

Myers, G., 2005. Disposable Cities: Garbage, Governance and Sustainable Development in Urban Africa. Burlington, VT: Ashgate Publishing Company.

Newell, S., 2012. The Modernity Bluff:Crime, Consumption, and Citizenship in Côte d'Ivoire. Chicago: Chicago University Press.

Mabala, R., 2011. 'Youth and 'The Hood': Livelihoods and Neighbourhoods. Environment and Urbanization, 23(1), pp. 157-181.

McFarlane, C., 2011. Learning the City: Knowledge and Translocal Assemblage. Oxford: John Wiley \& Sons.

Myers, G., 2011. African Cities: Alternative Visions of Urban Theory and Practice. London: Zed.

Potts, D. 2007. 'The State and the Informal in Sub-Saharan African Urban Economies: Revisiting Debates on Dualism. Working Paper No. 18, Crisis States Working Papers Series No. 2.

Richardson, C., and Skott-Myhre, H.A., eds. 2012. The Habitus of the Hood. Chicago: University of Chicago Press.

Robinson, J., and Parnell, S., 2012. (Re)Theorising Cities from the Global South: Looking Beyond Neoliberalism. Urban Geography, 33(4), pp. 593-617.

Simone, A., 2010. City Life from Jakarta to Dakar. New York: Routledge.

Sommers, M., 2010. Urban Youth in Africa. Environment and Urbanization 22(2), pp. 317-332. 
Sundaram, R., 2010. Pirate Modernity: Delhi’s Media Urbanism. New York:

Routledge.

Thieme, T., 2010. 'Youth, Waste and Work in Mathare: Whose Business and Whose Politics? Environment and Urbanization, 22(2), pp. 333-352.

Thieme, T.. 2013. The 'hustle' amongst youth entrepreneurs in Mathare's informal waste economy. Journal of Eastern African Studies, 7(3), pp. 389-412.

Thieme, T., 2015. Turning Hustlers Into Entrepreneurs, and Social Needs Into Market Demands: Corporate-Community Encounters in Nairobi, Kenya. Geoforum, 59, pp. 228-239.

Wacquant, L., 2008. Urban Outcasts: A Comparative Sociology of Advanced Marginality. Cambridge: Polity Press.

Wilson, W. 1987. The Truly Disadvantaged: The Inner City, the Underclass and Public Policy. Chicago: University of Chicago Press.

Waage, T., 2006. Coping with Unpredictability: 'Preparing for life' in Ngoundéré, Cameroon. Nordiska Afrikainstitutet, pp. 61 - 87.

Yaqub, S., 2009. Independent Child Migrants in Developing Countries: Unexplored Links in Migration and Development. Innocenti Working Paper IWP (1). Florence: Innocenti Research Centre.

Vigh, H., 2006. Navigating Terrains of War: Youth and Soldiering in Guinea-Bissau. New York: Berghahn.

Weiss, B., 2009. Street Dreams and Hip Hop Barbershops: Global Fantasy in Urban Tanzania. Bloomington: Indiana University Press. 